\title{
Interspecific Hybridization between Coreopsis leavenworthii and Coreopsis tinctoria Differently Affected Growth, Development, and Reproduction of Their Progeny
}

\author{
Sarah M. Smith ${ }^{1}$ and Zhanao Deng ${ }^{2}$ \\ University of Florida/IFAS, Department of Environmental Horticulture, Gulf Coast Research and \\ Education Center, 14625 County Road 672, Wimauma, FL 33598
}

\begin{abstract}
AdDitional INDEX wORDs. heterosis, hybrid breakdown, plant dry weight, plant height, pollen stainability, seedling emergence, seed production

Abstract. The genus Coreopsis L. is Florida's state wildflower; there is a strong interest in commercial production and large-scale planting of Coreopsis seed in Florida, especially the seed of Coreopsis leavenworthi Torr. \& A. Gray (COLE) and Coreopsis tinctoria Nutt. (COTI). Both species belong to the same section [Calliopsis (Reichenb.) Nutt.] within Coreopsis and were known to be cross-compatible and produce interspecific hybrids when hand-pollinated or grown in close proximity. Little was known about the effects of such hybridization on progeny growth, development, and reproduction, which are very important to seed production and planting. $F_{1}$ and $F_{2}$ interspecific populations between COLE and COTI were created in the greenhouse and then evaluated in replicated field studies in two growing seasons. Results showed that interspecific hybridization between COLE (as the maternal parent) and COTI (as the paternal parent) significantly increased the plant height (by $11.4 \%$ to $18.7 \%$ ), plant dry weight (by $38.6 \%$ to $63.9 \%$ ), and time to flower (by 3.7 to 9.8 days) of the $F_{1}$ and $F_{2}$ progeny of COLE $\times$ COTI crosses. By contrast, interspecific hybridization between COTI (as the maternal parent) and COLE (as the paternal parent) did not cause significant changes in these characteristics of the $F_{1}$ and $F_{2}$ progeny of COTI $\times$ COLE crosses. The differences between the two species in responding to interspecific hybridization suggest that COTI played a more dominant role in controlling plant height, dry weight, and time to flower in its hybrids with COLE. Results pooled from all $F_{1}$ or $F_{2}$ progeny of reciprocal interspecific crosses showed that interspecific hybridization did not seem to affect the plant height and seedling emergence of $F_{1}$ and $F_{2}$ progeny but affected the dry weight, time to flower, pollen stainability, and seed production (per seed head) of these progeny. Heterosis was observed in the time to flower of $F_{1}$ progeny in 2009. Heterosis was also evident in $F_{1}$ progeny's dry weight but followed with slight hybrid breakdown in $F_{2}$ progeny. Pollen stainability and seed production both showed significant breakdown in $F_{1}$ and $F_{2}$ progeny: $53.3 \%$ to $81.1 \%$ reduction in pollen stainability and $\mathbf{1 2 . 6 \%}$ to $38.2 \%$ reduction in seed production, respectively. Chromosome mispairing resulting from reported reciprocal translocations between the chromosomes of COLE and COTI might be the primary cause of low pollen stainability and seed production in $F_{1}$ and $F_{2}$ progeny. Maternal effects were detected in plant height and dry weight of $F_{1}$ and $F_{2}$ progeny. These results showed that interspecific hybridization between COLE and COTI would result in deleterious effects to both species; thus, it is very important to prevent crosspollination and hybridization between them in commercial seed production and native plantings.
\end{abstract}

Planting natives has become increasingly common in national/state parks, highway right-of-ways, and home landscapes (Rogers and Montalvo, 2004). One group of native plants frequently used in such plantings in the United States is native wildflowers. Many states have implemented wildflower planting programs for highway beautification and revegetation (Kabat et al., 2007; Texas Department of Transportation, 2011). Planting native wildflowers has resulted in multiple benefits, including increased aesthetic values, enhanced wildlife habitats, and reduced maintenance costs (Bryant and Harper-Lore,

Received for publication 19 Sept. 2014. Accepted for publication 10 Oct. 2014. This is part of a PhD dissertation of Sarah Smith.

Dr. David Clark (co-chair of the graduate committee) and Drs. Jeffery G. Norcini, Frederick G. Gmitter, Jr., and Kenneth H. Quesenberry (committee members) provided very valuable reviews, comments, and suggestions, for which we are very grateful. We thank Joyce Jones and Gail Bowman for their technical assistance and the Florida Wildflower Foundation, Inc. for financial support of this study.

${ }^{1}$ Former Graduate Student. Current address: HM-Clause, 9241 Mace Boulevard, Davis, CA 95618.

${ }^{2}$ Corresponding author. E-mail: zdeng@ufl.edu.
1997). Members of the family Asteraceae are among the native wildflowers commonly planted in the United States.

When cross-compatible native plant species are brought into close proximity for seed production or planting, interspecific hybridization can occur (Ellstrand, 1992). Interspecific hybridization could lead to genetic contamination of native wildflower seed being produced. If interspecific hybrids have reduced seed viability and/or plant fitness, interspecific hybridization can result in poor establishment, performance, and/or sustainability of the transplanted materials. Interspecific hybridization may also disrupt native taxa's local adaptation and genetic structure that have developed during natural selection and evolution (Laikre et al., 2010). Interspecific hybridization might have contributed to the demise of some rare plant species (Largiadèr, 2007; Levin et al., 1996). The potential adverse effects of unintended interspecific hybridization on native plants have become a major concern to native plant producers, growers, and users.

The genus Coreopsis (Asteraceae) is Florida's state wildflower (Florida Legislature, 2014). One of its species, Coreopsis leavenworthii, is distributed widely in Florida (U.S. Department of Agriculture, 2012; Wunderlin and Hansen, 2004). COLE 
habitats include roadside ditches, wet pine flatwoods, and other moist disturbed sites (Kabat et al., 2007). COLE plants can produce a dense flower cover over the foliage and are highly desirable for use in highway beautification projects. Seed (achenes) of this species have been and continue to be in high demand in Florida. Commercially produced COLE seed were sold for as much as \$258 per kilogram (in 2006), and the seed costs for planting COLE along highways reached as high as $\$ 4300$ per hectare. COLE seed germination and progeny growth, development, and sustainability are very important to COLE seed producers and end users.

A closely related species of COLE, Coreopsis tinctoria, is distributed in all states of the United States except Alaska, Nevada, and Utah, and it has been highly recommended for highway beautification in several states. COTI seed are commercially produced in a number of states, mainly Texas. Naturalized COTI populations are codistributed with COLE populations in several counties in Florida (Wunderlin, 1998). There has been a significantly increased interest in planting more COTI along Florida highways. COLE and COTI both belong to the Calliopsis section within Coreopsis and are known to be outcrossing species (Smith, 1976; Wunderlin, 1998). When grown in close proximity in Florida under field conditions, COLE was cross-pollinated by COTI to some extent, resulting in the production of unwanted interespecific hybrids (Smith and Deng, 2012). Parker (1973) showed that COLE and COTI were cross-compatible after hand pollination in the greenhouse, and their $F_{1}$ hybrids showed reduced pollen stainability. Smith (1976) indicated the existence of several structural differences, including reciprocal translocations, between the chromosomes of COLE and COTI. Thus, some levels of male and/or female sterility would be expected in the interspecific hybrids of COLE and COTI. However, no studies have been carried to quantify the actual effects of COLE and COTI interspecific hybridization on their progeny's plant growth, development, and reproduction. This study aimed to fill this knowledge gap by creating COLE and COTI interspecific hybrids in the greenhouse and evaluating their hybrids in replicated field studies. This study also intended to assess the plant growth, development, and reproduction of $\mathrm{F}_{2}$ interspecific hybrids to gain a better understanding of the persistence of the effects of interspecific hybridization on COLE and COTI hybrids.

\section{Materials and Methods}

\section{Seed source and initial parental plants}

The COLE and COTI seed used in this study were collected by N. Bissett from a natural COLE population at the Reedy Creek Mitigation Bank in Polk County, FL, and purchased from the Wildseed Farms in Fredericksburg, TX, respectively. Seed were germinated as previously described by Smith and Deng (2012).

The initial COLE parental plants consisted of 40 individuals from the previously mentioned seed source, and the initial COTI parental plants were made up of 35 individuals from that seed source. Parental plants were grown in 3.2-L plastic containers (one individual per container) in a greenhouse at the University of Florida Gulf Coast Research and Education Center, Wimauma, FL (GCREC). Containers were filled with a commercial potting mix [Vergrow Container Mix A (VCMA); Verlite Co., Tampa, FL] and top-dressed with $8.6 \mathrm{~g}$ of $15 \mathrm{~N}-3.9 \mathrm{P}-10 \mathrm{~K}$ controlled-release fertilizer $\left(\right.$ Osmocote ${ }^{\circledR}$ 5-6 month; Scott's, Marysville, $\mathrm{OH}$ ) per container. Temperatures in the greenhouse were between 23.9 and $29.4^{\circ} \mathrm{C}$. Plants were grown under natural light and photoperiods.

\section{Hand pollination and population development}

Hand pollination was performed on these parental plants from June to Aug. 2007 to make interspecific crosses and produce interspecific $F_{1}$ seed (Fig. 1). In the meantime, hand pollination was done to make intraspecific outcrosses within each species to produce seed for the reference populations. Subsequently, $F_{1}$ hybrids were grown and hand-pollinated in Nov. 2008 to produce interspecific $F_{2}$ populations (Fig. 1).

INTERSPECIFIC CROSSES AND HYBRID POPULATIONS. Reciprocal interspecific crosses between COLE and COTI were made to produce $F_{1}$ hybrid seed. For simplicity, seed and progeny from the COLE $\times$ COTI crosses were referred to as COLE $F_{1}$, and seed and progeny from the COTI $\times$ COLE crosses were referred to as COTI $F_{1}$. Pollen collection, flower bagging, flower pollination, seed harvesting, and seed processing were performed as previously described by Smith (1976) and Smith and Deng (2012). To avoid potential self-pollination, flower heads (capitula) were bagged when they were immature and then pollinated before disc flowers shed pollen. Ten flower heads per each of the 40 COLE individuals were hand-pollinated with bulked pollen from 35 COTI individuals (Fig. 1). Seed produced by pollinated COLE flower heads were harvested and bulked by COLE parental individual, resulting in $40 \mathrm{COLE} \mathrm{F}_{1}$ families (Fig. 1). Five flower heads per each of the 35 COTI individuals were hand-pollinated with bulked pollen from the 40 COLE individuals (Fig. 1). Seed produced by pollinated COTI flower heads were harvested by flower head and bulked by COTI parental plants, resulting in $35 \mathrm{COTI}_{1}$ families.

To create COLE $\mathrm{F}_{2}$ and COTI $\mathrm{F}_{2}, \mathrm{COLE}_{1}$ and COTI $\mathrm{F}_{1}$ seed were germinated on the surface of the commercial potting

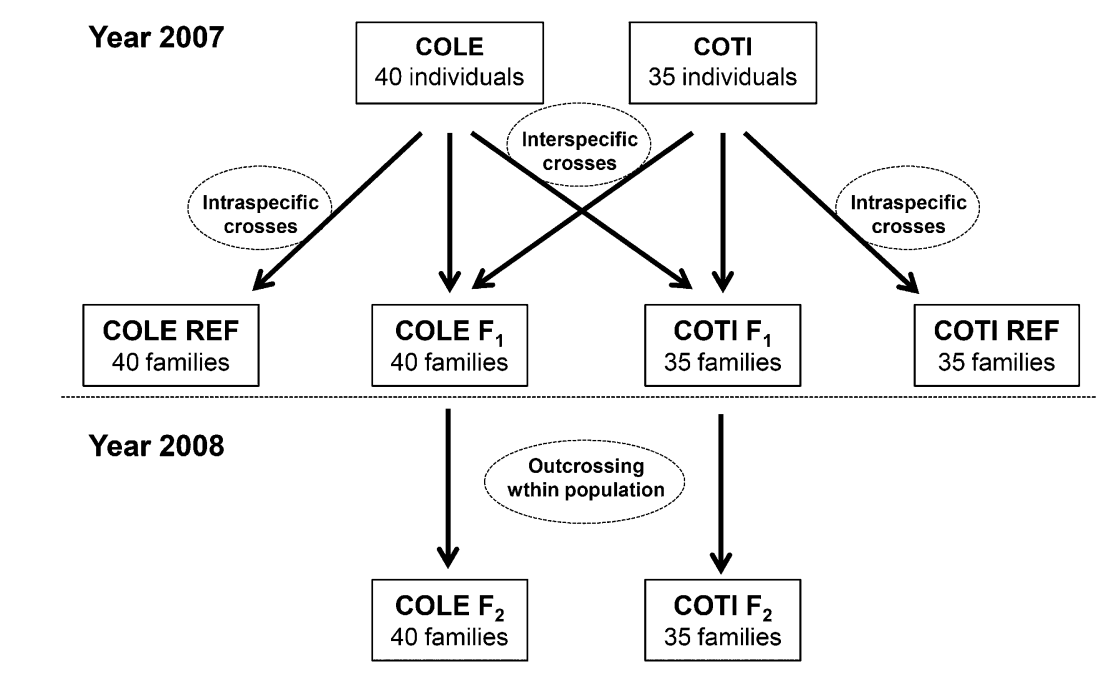

Fig. 1. Intraspecific and interspecific crosses made in 2007-08 at the Gulf Coast Research and Education Center in Wimauma, FL, to produce six populations, COLE REF, COLE $\mathrm{F}_{1}, \mathrm{COLE} \mathrm{F}_{2}$, COTI REF, COTI $F_{1}$, and COTI $F_{2}$, that were used in field studies in 2009 and 2010 to assess the effects of interspecific hybridization between COLE (Coreopsis leavenworthii) and COTI $(C$. tinctoria) on their progeny's growth, development, and reproduction. 
mix (Fafard 3B; Sun Gro Horticulture, Agawam, MA) in plastic containers (15 cm diameter, $1.2 \mathrm{~L}$ vol.). Seedlings were grown under natural light and photoperiods in a greenhouse at GCREC, and temperatures in the greenhouse were maintained between 23.9 and $29.4{ }^{\circ} \mathrm{C}$. Plants were fertilized by applying $8.6 \mathrm{~g}$ of $15 \mathrm{~N}-3.9 \mathrm{P}-10 \mathrm{~K}$ controlled-release fertilizer (Osmocote ${ }^{\circledR}$ 5-6 month) to each container. One $F_{1}$ plant was randomly selected from each COLE $F_{1}$ or COTI $F_{1}$ family, resulting in 40 COLE $_{1}$ and $35 \mathrm{COTI} \mathrm{F}_{1}$ progeny. Pollen was collected from $40 \mathrm{COLE} \mathrm{F}_{1}$ progeny, bulked, and applied to 10 flower heads on each of the 40 COLE $F_{1}$ progeny that were bagged at the flower bud stage. $\mathrm{F}_{2}$ seed were harvested from 400 pollinated flower heads by flower head, counted, and bulked by COLE $\mathrm{F}_{1}$ family, resulting in $40 \mathrm{COLE}_{2}$ families. Thirty-five COTI $\mathrm{F}_{2}$ families were produced similarly, except that five flower heads on each COTI $\mathrm{F}_{1}$ progeny were pollinated with pollen collected from 35 COTI $\mathrm{F}_{1}$ individuals.

INTRASPECIFIC CROSSES AND REFERENCE POPULATIONS. TWo intrapecific populations were created as the reference populations [hereafter referred to as COLE REF and COTI REF (Fig. 1)]. On each COLE maternal plant, five flower heads were bagged at the flower bud stage and pollinated with the bulked pollen from the 40 COLE paternal plants. Seed were harvested by flower head, counted, and bulked by COLE maternal plant, resulting in 40 COLE REF families. Similarly, five flower heads on each COTI maternal plant were bagged and then pollinated with bulked pollen from 35 COTI paternal plants, resulting in 35 COTI REF families.

\section{Assessing seed production and seedling emergence of interspecific $\mathbf{F}_{1}$ hybrids grown in the greenhouse}

Assessment of seed production was conducted in conjunction with the described hand pollination and population development. Seed produced by pollinated flower heads on COLE $\mathrm{F}_{1}$ and COTI $\mathrm{F}_{1}$ individuals were harvested and counted. Seed production data for COLE $\mathrm{F}_{1}$ were collected from 400 flower heads on 40 COLE $F_{1}$ individuals (10 flower heads per $F_{1}$ individual), and seed production data for COTI $\mathrm{F}_{1}$ were from 175 flower heads on 35 COTI $F_{1}$ individuals (five flower heads per $\mathrm{F}_{1}$ individual).

The seedling emergence test consisted of three replicates, 100 seed per replicate per $F_{1}$ individual. Seed were germinated on the surface of VCMA in plastic containers $(532 \mathrm{~mL} /$ container $)$ in a greenhouse under conditions described previously. Seedlings were counted 3 weeks after seed were sowed.

The seed production and seedling emergence data of $F_{1}$ hybrids were statistically analyzed using PROC GLM and Tukey's Studentized range test in SAS (Version 9.3; SAS Institute, Cary, NC) for analysis of variance (ANOVA) and mean separation (when significant differences were shown in ANOVA). The seed production and seedling emergence of COLE and COTI intraspecific crosses were used as the baseline for comparisons. Seed production and seedling emergence of the COLE and COTI intraspecific outcrosses were determined in the same way as described previously for $\mathrm{F}_{1}$ hybrids.

\section{Assessing plant growth, development, and reproduction of interspecific $F_{1}$ and $F_{2}$ hybrids in the field}

Two field studies were conducted, one in 2009 and one in 2010 , to assess the effects of interspecific hybridization on plant growth, development and seed production, and seedling emergence of COLE and COTI interspecific hybrids. In each field study, individuals from COLE $\mathrm{F}_{1}, \mathrm{COLE} \mathrm{F}_{2}, \mathrm{COTI} \mathrm{F}_{1}$, and
$\mathrm{COTI}_{2}$ as well as COLE REF and COTI REF were grown in the greenhouse and subsequently in the field and then assessed for the mentioned vegetative and reproductive characteristics. Plant growing conditions and methods for data collection were as follows.

Growing Conditions. For the 2009 field study, seed were sowed on 19 Feb. 2009 into 32-cell flats $(148 \mathrm{~mL} / \mathrm{cell}$; Speedling, Sun City, FL) filled with a commercial potting mix (Fafard 3B; Sun Gro Horticulture). Seed were placed on the surface of the mix and germinated under intermittent mist in the greenhouse at GCREC with the temperatures between $29.4{ }^{\circ} \mathrm{C}$ (day) and $23.9{ }^{\circ} \mathrm{C}$ (night) and under natural light. Seedlings were transplanted to 128 -cell flats $(31 \mathrm{~mL} / \mathrm{cell}$; Speedling) containing the Fafard 3B potting mix on 14 to 16 Mar. 2009, grown in the greenhouse for $50 \mathrm{~d}$, and then transplanted to field beds on 4 May 2009. Soil in the field was a mix of Myakka, Haplaquents, and St. Johns sandy soil containing $\approx 1 \%$ organic matter and a $\mathrm{pH}$ value between 6.1 and 6.5. Ground beds were $25 \mathrm{~cm}$ high, $71 \mathrm{~cm}$ wide at the top, and $81 \mathrm{~cm}$ wide at the base, fumigated on 27 Feb. 2009 with 50\% methyl bromide:50\% chloropicrin at the rate of $197 \mathrm{~kg} \cdot \mathrm{ha}^{-1}$, and covered with whiteon-black plastic. Two rows of Coreopsis plants were transplanted along the bed with $40 \mathrm{~cm}$ between-row spacing and $55.9 \mathrm{~cm}$ in-row spacing. The transplanted plants were irrigated through drip tapes and fertilized with a total of $169 \mathrm{~kg} \cdot \mathrm{ha}^{-1}$ nitrogen, $37 \mathrm{~kg} \cdot \mathrm{ha}^{-1}$ phosphorus, and $210 \mathrm{~kg} \cdot \mathrm{ha}^{-1}$ potassium.

For the 2010 field study, seed were sowed on 20 Jan. 2010 into 32-cell flats (Speedling) filled with the Fafard 3B potting mix and germinated as described for the 2009 study. Seedlings were transplanted to 128-cell flats (Speedling) filled with the Fafard $3 \mathrm{~B}$ potting mix on 15 to $16 \mathrm{Feb} .2010$ and grown in the flats in the greenhouse for $50 \mathrm{~d}$. Plants were transplanted to the field on 5 Apr. 2010. Field conditions and ground beds were the same as those described for the 2009 study, except that a single row of Coreopsis plants was transplanted along the bed with an in-row spacing of $30.5 \mathrm{~cm}$, no fertilization was applied, and irrigation was through a seepage system (Geraldson et al., 1965).

Data collection. Plant height [H (centimeter)] was measured from the bed surface to the tallest point of each plant. Plant height measurements were taken on 13 July 2009 for the 2009 study and on 2 June 2010 for the 2010 study. Plants in the 2009 study were harvested from the field on 15 to 21 July, 72 to $78 \mathrm{~d}$ after the plants were transplanted to the field, and air-dried between 21.1 and $34.4{ }^{\circ} \mathrm{C}$ for more than 4 weeks before plant dry weights (DWs) were taken individually. Plants in the 2010 study were harvested from the field on 15 to 17 June, 71 to $73 \mathrm{~d}$ after field planting, and air-dried at $37.8{ }^{\circ} \mathrm{C}$ and $20 \%$ relative humidity for 3 to 4 weeks before DWs were recorded.

The time to flower [TTF (days)] for the 2009 study was recorded from 23 Apr. to 31 July 2009 and for the 2010 study from 28 Apr. to 7 June 2010. The date was recorded when the first flower on the plant opened, and the number of days from seed sowing to first open flower was counted as the time to flower.

Seed production (SP) was determined by collecting five seed heads per plant in the field, bulking the seed heads, and counting seed per five seed heads. Seed heads were collected on 8 July 2009 for the 2009 study and on 2 and 3 June 2010 for the 2010 study. Seedling emergence (E) was determined using the seed collected from the 2009 study. For each plant in the field, 100 seed were sowed in 32-cell Speedling flats filled with Fafard 3B; seedlings were counted 3 weeks after sowing. 
Seed germination conditions were the same as described previously.

For pollen stainability (PS), flower heads were collected in Sept. and Oct. 2009. Ten flower heads per line were collected before anthesis and stained in $200 \mu \mathrm{L}$ of lactophenol cotton blue stain (ENG Scientific, Clifton, NJ) for $\approx 3 \mathrm{~h}$ at room temperature. Approximately $10 \mu \mathrm{L}$ of the stain solution containing pollen grains was pipetted onto a glass slide and a coverslip was placed on top of the stain solution. Three slides per line were prepared and pictures of four fields per slide were taken under a bright field microscope (BH-2; Olympus, Tokyo, Japan). An average of 818 pollen grains per individual was counted. Pollen grains were considered stainable if they were stained to a deep, uniform blue, and were full and plump.

Field experimental Design. After the described seedling emergence tests, some of the $F_{1}$ families did not have enough seed left for field studies. Thus, 25 families per population were grown and evaluated in the 2009 field study and 13 to 25 families per population in the 2010 field study. For the 2009 study, 15 individuals per family were grown and evaluated, resulting in a total of 375 individuals per population for data collection. These individuals were labeled and planted in 15 randomized complete blocks (RCBs) in the field. Each block consisted of 150 individuals from 150 families of six populations (COLE REF, COLE $\mathrm{F}_{1}, \mathrm{COLE} \mathrm{F}_{2}$, COTI REF, COTI $\mathrm{F}_{1}$, and COTI $\mathrm{F}_{2}$ ), that is, one individual per family and 25 individuals per population per block. For the 2010 study, eight individuals per family were grown and evaluated, resulting in 200 individuals per population. These individuals were planted in eight RCBs in the field.

Statistical analysis. Data collected from individual plants for the mentioned characteristics were used for ANOVA of the differences among populations (CREF REF, COLE $\mathrm{F}_{1}$, COLE $\mathrm{F}_{2}$, COTI REF, COTI $\mathrm{F}_{1}$, and COTI $\mathrm{F}_{2}$ ). ANOVA was performed with the PROC GLM in SAS (SAS Institute, 1997). Seedling emergence and pollen stainability data were transformed using the arcsine square root method before ANOVA. When significant differences were detected in ANOVA, the Tukey's Studentized range test was performed in SAS for mean comparison.

\section{Results}

Seed production and seedling emergence of interspecific $F_{1}$ hybrids grown in the greenhouse and hand-pollinated

SEEd PRoduction. Intraspecific crosses among COLE individuals produced an average of 50.2 seed per seed head (based on 400 seed heads), and intrapecific crosses among COTI individuals produced an average of 14.9 seed per seed head (based on 175 seed heads) (Fig. 2A). COLE $\times$ COTI $F_{1}$ progeny produced an average of 35.3 seed (based on 400 seed heads) (Fig. 2A), 29.7\% reduction from the SP by COLE intraspecific outcrosses. The mean SP by COTI $\times$ COLE $F_{1}$ progeny was 31.9 seed, which was $214.1 \%$ of the SP by the COTI intraspecific outcrosses (Fig. 2A). Overall, $F_{1}$ progeny of the COLE $\times$ COTI cross and its reciprocal cross COTI $\times$ COLE had similar mean SP (35.3 and 31.9 seed). It should be pointed out that as a result of time and space constraints, handpollination of COLE $\times$ COTI $F_{1}$ or COTI $\times$ COLE $F_{1}$ progeny was performed only in one greenhouse environment in 2008.

Interestingly, COLE individuals produced $23.3 \%$ more seed (61.9 seed per seed head) when pollinated with COTI pollen than when pollinated with COLE pollen. The difference was

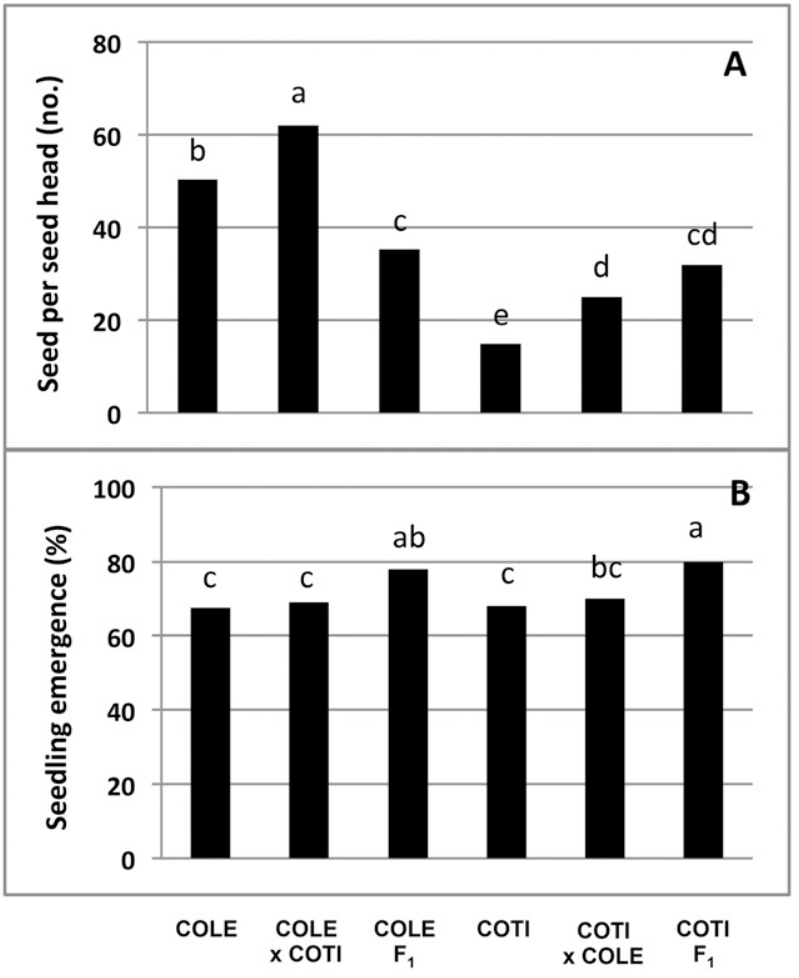

Fig. 2. Mean seed production per seed head (A) and mean seedling emergence (B) from six types of crosses: COLE $=$ intraspecific among 40 COLE (Coreopsis leavenworthii) individuals, $\mathrm{COLE} \times \mathrm{COTI}=$ interspecific crosses between 40 COLE individuals and 35 COTI (C. tinctoria) individuals, COLE $\mathrm{F}_{1}=$ outcrossing among $40 \mathrm{COLE} \times \mathrm{COTI}_{1}$ progeny, $\mathrm{COTI}=$ intraspecific crossing among 35 COTI individuals, COTI $\times$ COLE $=$ interspecific crosses between 35 COTI individuals and 40 COLE individuals, and COTI $F_{1}=$ outcrossing among $35 \mathrm{COTI} \times$ COLE $\mathrm{F}_{1}$ progeny. COLE and COTI intraspecific crosses and COLE $\times$ COTI and COTI $\times$ COLE interspecific crosses were made by hand pollination in Wimauma, FL, in Summer 2007. COLE $F_{1}$ and COTI $F_{1}$ crosses were made by hand pollination in a greenhouse in Summer 2008. Means followed by the same letter are not significantly different by Tukey's Studentized range test at $P \leq 0.05$.

statistically significant. Similarly, COTI individuals produced significantly more seed (25.0 seed per seed head, or $67.8 \%$ more) when pollinated with COLE pollen than pollinated with COTI pollen (Fig. 2A).

SEEDLING EMERGENCE. The seedling emergence for seed from COLE and COTI intraspecific crosses was similar, $67.7 \%$ and $67.9 \%$, respectively (Fig. 2B). The seedling emergence for seed from interspecific crosses was also similar, $69.7 \%$ and $71.7 \%$ for COLE $\times$ COTI and COTI $\times$ COLE crosses, respectively (Fig. 2B). These results indicate that seed from COLE and COTI interspecific crosses produced seedlings as well as those from COLE or COTI intraspecific crosses.

The mean seedling emergence for seed produced by COLE $\times$ COTI $F_{1}$ progeny was $79.1 \%$, significantly higher than the seedling emergence of seed produced by COLE $\times$ COLE and COLE $\times$ COTI crosses (Fig. 2B). The mean seedling emergence for the seed produced by COTI $\times$ COLE $_{1}$ progeny was $83.0 \%$, also significantly higher than the seedling emergence of the seed from COTI $\times$ COTI or COTI $\times$ COLE crosses.

Plant growth and dry weight of $F_{1}$ and $F_{2}$ hybrids under field conditions

Plant height. There were significant differences between years and among populations for plant height (Table 1). The 
mean plant height of the various populations in 2010 was significantly smaller than that in $2009: 10.5 \%$ to $14.2 \%$ smaller for COLE REF and COTI REF, $17.6 \%$ to $18.1 \%$ smaller for the $F_{1}$ populations, and $9.7 \%$ to $11.1 \%$ smaller for the $F_{2}$ populations (Table 2).

In 2009, the mean plant height of the COLE REF and COTI REF populations was 69.7 and $95.6 \mathrm{~cm}$, respectively (Fig. 3A). In 2010, the mean plant height of the COLE REF and COTI REF populations was 59.8 and $85.6 \mathrm{~cm}$, respectively (Fig. 3B). Thus, COLE plants were, on average, $25.9 \mathrm{~cm}(27.1 \%)$ and 25.8 $\mathrm{cm}(30.1 \%)$ shorter than COTI REF plants in 2009 and 2010 , respectively (Table 3 ).

This height difference between COLE and COTI seemed to have affected the plant height of $\mathrm{F}_{1}$ and $\mathrm{F}_{2}$ hybrids. The mean height of COLE $F_{1}$ was $11.0 \%$ (in 2009) and 11.5\% (in 2010) shorter than that of COTI $F_{1}$, and the mean height of COLE $F_{2}$ was $15.2 \%$ (in 2009) and $13.4 \%$ (in 2010) shorter than that of
$\mathrm{COTIF}_{2}$ (Fig. $3 \mathrm{~A}$ and B). These data indicate that when COLE was the maternal parent, progeny were shorter than those whose maternal parent was COTI. The difference was consistent from $F_{1}$ to $F_{2}$ generation, suggesting a maternal effect from COLE on the plant height of its interspecific hybrids with COTI.

When the data from COLE $F_{1}$ and COTI $F_{1}$ in each year were combined, the mean plant height of all $\mathrm{F}_{1}$ progeny was similar to the midparent value and the average height of COLE REF and COTI REF in 2009 and 2010 (Table 2). Similarly, the mean height of all $F_{2}$ progeny in both 2009 and 2010 was similar to the mean height of COLE REF and COTI REF. These data suggest that interspecific hybridization did not have significant effects on the overall mean height of $F_{1}$ or $F_{2}$ hybrids (Table 3). Additionally, the mean height of all COLE $\mathrm{F}_{2}$ and COTI $F_{2}$ hybrids was similar to the mean height of all COLE $\mathrm{F}_{1}$ and COTI $\mathrm{F}_{1}$ hybrids.

Table 1. Analysis of variance for six characteristics of six Coreopsis populations, COLE REF (C. leavenworthii intraspecific population), COLE $\mathrm{F}_{1}\left(C\right.$. leavenworthii $\times$ Coreopsis tinctoria interspecific $\mathrm{F}_{1}$ population), COLE $\mathrm{F}_{2}$ (selfed COLE $\mathrm{F}_{1}$ population), COTI REF $(C$. tinctoria intraspecific population), $\mathrm{COTIF}_{1}$ (C. tinctoria $\times$ C. leavenworthii interspecific $\mathrm{F}_{1}$ population), and COTI $\mathrm{F}_{2}$ (selfed COTI $\mathrm{F}_{1}$ population), that were evaluated in Wimauma, FL, in 2009 and/or 2010.

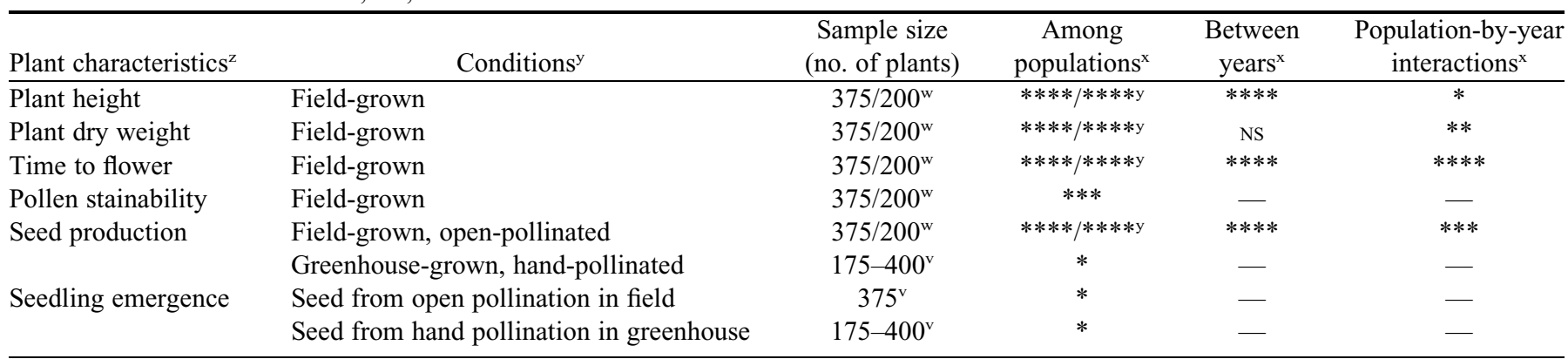

zPlant height was measured from bed (or ground) surface to the tallest point of plants in centimeter. Plant weight was the dry weight of all aboveground plant parts. Time to flower was calculated from the date when seed were sown to the first day plants came into flowering. Pollen stainability was determined using the vital dye lactophenol cotton blue stain. Seedling emergence was based on counting seedlings emerged 1 month after seed were sown.

${ }^{y}$ In 2009, Coreopsis plants were planted in mulched, raised, and fumigated beds, irrigated with drip tapes, and fertilized with liquid fertilizer. In 2010, Coreopsis plants were grown in similarly prepared beds, but irrigated through a seepage system and not fertilized. Greenhouse-grown plants were grown in plastic containers filled with a commercial potting mix.

${ }^{\mathrm{x}}$ Analysis of variance was performed with the PROC GLX in SAS (Version 9.3; SAS Institute, Cary, NC). *, **, ***, and **** indicate statistical significance at $P=0.05,0.01,0.001$, and 0.0001 , respectively. NS = non-statistically significant. Statistical significance among populations in 2009 (before slash) and 2010 (after slash).

wThe total number of Coreopsis individuals per population evaluated in 2009 (before slash) and 2010 (after slash).

vNumber of seed heads were sampled in 2007 or 2008.

Table 2. Midparent values of Coreopsis leavenworthii and C. tinctoria and the mean values of Coreopsis interspecific $\mathrm{F}_{1}$ and $\mathrm{F}_{2}$ progeny for six characteristics evaluated in Wimauma, FL, in 2009 and 2010.

\begin{tabular}{|c|c|c|c|c|c|c|}
\hline \multirow[b]{2}{*}{ Plant characteristics } & \multicolumn{3}{|c|}{2009} & \multicolumn{3}{|c|}{2010} \\
\hline & Midparent $^{z}$ & $\mathrm{~F}_{1}^{\mathrm{y}}$ & $\mathrm{F}_{2}{ }^{\mathrm{x}}$ & Midparent & $\mathrm{F}_{1}$ & $\mathrm{~F}_{2}$ \\
\hline Plant ht $[$ mean \pm SE $(\mathrm{cm})]$ & $82.6 \pm 1.2$ & $87.3 \pm 1.7$ & $83.5 \pm 1.5$ & $72.7 \pm 1.2$ & $71.7 \pm 2.2$ & $75.1 \pm 1.4$ \\
\hline Plant dry wt $[\text { mean } \pm \mathrm{SE}(\mathrm{kg})]^{\mathrm{w}}$ & $0.125 \pm 0.002$ & $0.157 \pm 0.010$ & $0.128 \pm 0.007$ & & & \\
\hline Pollen stainability $[$ mean $\pm \operatorname{SE}(\%)]$ & $18.4 \pm 3.7$ & $5.4 \pm 1.1$ & $7.0 \pm 1.4$ & - & - & - \\
\hline Seed production—-field [mean \pm SE (no. seed)] & $446.1 \pm 12.0$ & $315.5 \pm 13.4$ & $344.3 \pm 11.8$ & $614.1 \pm 21.9$ & $517.2 \pm 19.7$ & $542.9 \pm 16.8$ \\
\hline Seedling emergence-field [mean \pm SE $(\%)]$ & $49.3 \pm 1.1$ & $50.3 \pm 1.4$ & $47.8 \pm 1.7$ & - & - & - \\
\hline
\end{tabular}

${ }^{\mathrm{z}}$ Calculated as the mean value of two parental populations COLE REF (C. leavenworthii intraspecific population) and COTI REF (C. tinctoria intraspecific population) in respective years.

${ }^{\mathrm{y}}$ Calculated as the mean value of two $\mathrm{F}_{1}$ populations COLE $\mathrm{F}_{1}\left(C\right.$. leavenworthii $\times$ C. tinctoria interspecific $\mathrm{F}_{1}$ population $)$ and COTI $\mathrm{F}_{1}$ (C. tinctoria $\times$ C. leavenworthii interspecific $\mathrm{F}_{1}$ population) in respective years.

${ }^{\mathrm{x}}$ Calculated as the mean value of two $\mathrm{F}_{2}$ populations COLE $\mathrm{F}_{2}$ (selfed COLE $\mathrm{F}_{1}$ population) and COTI $\mathrm{F}_{2}$ (selfed COTI $\mathrm{F}_{1}$ population) in respective years.

w2009 and 2010 data were combined because no significant differences were detected in analysis of variance. 


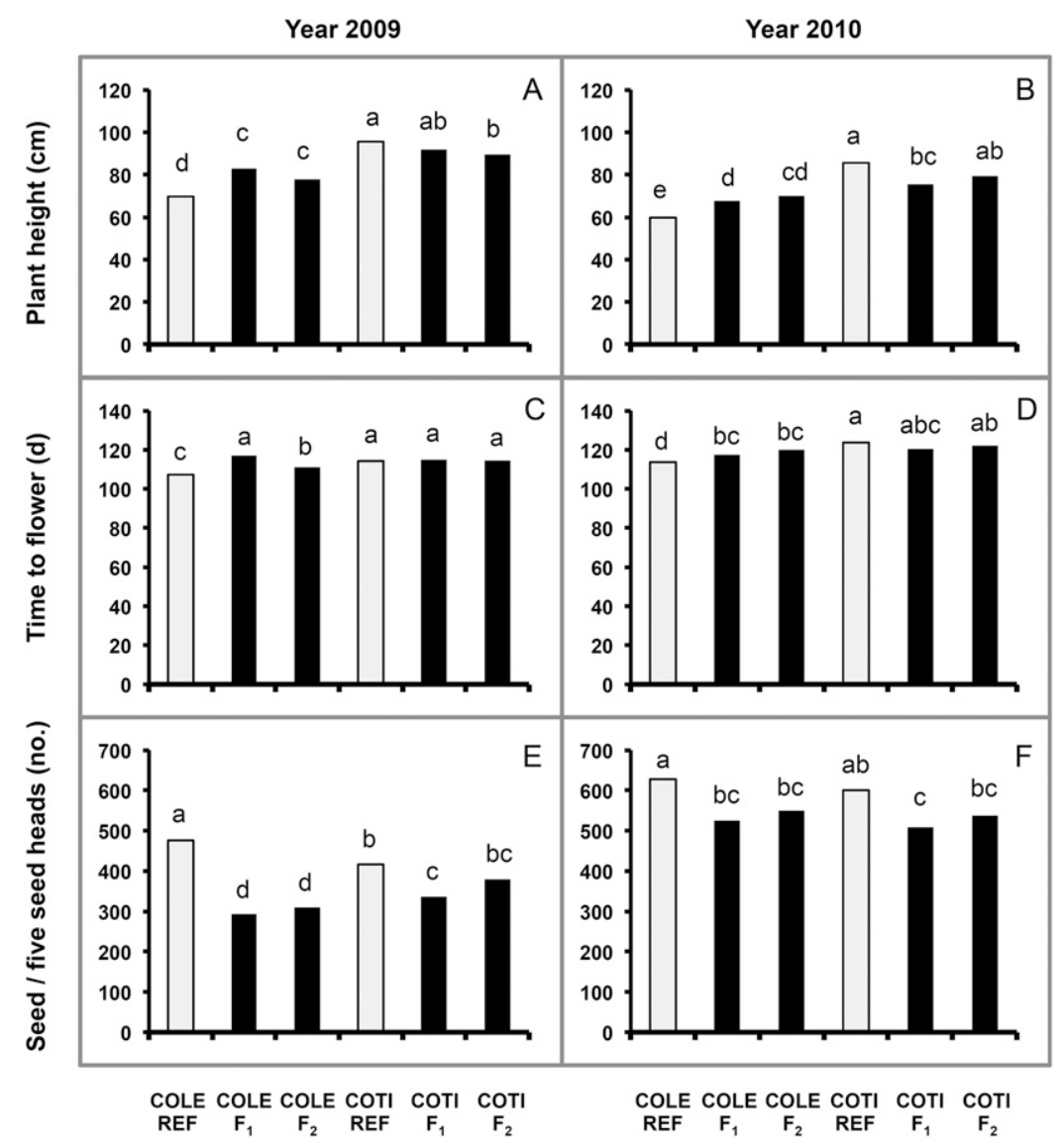

Fig. 3. Mean plant heights (A-B), mean numbers of days or time to flower $(\mathbf{C}-\mathbf{D})$, and mean seed production (per five seed heads) (E-F) of six populations in the $2009(\mathbf{A}, \mathbf{C}, \mathbf{E})$ and the $2010(\mathbf{B}, \mathbf{D}, \mathbf{F})$ field studies. COLE $=$ Coreopsis leavenworthii, and COTI $=C$. tinctoria. COLE REF $=$ progeny of COLE intraspecific outcrosses, $\mathrm{COLE}_{1}=$ interspecific $\mathrm{F}_{1}$ progeny of COLE and COTI, COLE $\mathrm{F}_{2}=$ interspecific $\mathrm{F}_{2}$ progeny of COLE and COTI, COTI REF = progeny of COTI intraspecific outcrosses, COTI $F_{1}=$ interspecific $F_{1}$ progeny of COTI and COLE, and COTI $F_{2}=$ interspecific $F_{2}$ progeny of COTI and COLE. Means within year followed by the same letter are not significantly different by Tukey's Studentized range test at $P \leq 0.05$.

However, the mean height of COLE $F_{1}$ in 2009 was $82.7 \mathrm{~cm}$, $18.7 \%$ greater than that of COLE REF (Fig. 3A). The mean height of COLE $\mathrm{F}_{1}$ in $2010(67.8 \mathrm{~cm})$ was also significantly greater $(13.3 \%)$ than that of COLE REF (Fig. 3B). The mean height of COLE $F_{2}$ was $77.6 \mathrm{~cm}$ in 2009 and $70.1 \mathrm{~cm}$ in 2010 , $11.4 \%$ and $17.2 \%$ greater than the value of COLE REF, but similar to the value of COLE $F_{1}$ in both years (Fig. 3A and B). These data suggest that hybridization with COTI increased the plant height of COLE $F_{1}$ and $F_{2}$ progeny (Table 3 ).

On average, COTI $\mathrm{F}_{1}$ progeny were significantly shorter $(11.6 \%$ ) than COTI REF individuals in 2010 (Fig. 3B). COTI F 2 progeny were significantly shorter $(6.5 \%)$ than COTI REF individuals in 2009 (Fig. 3A). These data showed that hybridization with COLE could decrease the plant height of COTI $F_{1}$ and $\mathrm{F}_{2}$ progeny.

Plant dRy weight. There were no significant differences between years for DW (Table 1), so the data from the 2 years were combined to determine the effects of interspecific hybridization on DW. The mean DW of COLE REF $(0.083 \mathrm{~kg})$ was significantly less than that of COTI REF $(0.156 \mathrm{~kg})$ (Fig. 4A). The $88.0 \%$ greater DW of the COTI plants over the COLE plants seemed to impose a maternal effect on the $\mathrm{F}_{1}$ and even $\mathrm{F}_{2}$ population. The mean DW of COTI $F_{1}$ was $0.165 \mathrm{~kg}, 21.3 \%$ greater than that of COLE $\mathrm{F}_{1}(0.136 \mathrm{~kg})$, and the mean DW of COTI $F_{2}$ was $0.140 \mathrm{~kg}$, $21.7 \%$ greater than that of COLE $\mathrm{F}_{2}(0.115$ kg) (Fig. 4A). The maternal effect was consistent from $F_{1}$ to $F_{2}$ generation (Table 3 ).

The mean DW of COLE $F_{1}$ and $F_{2}$ progeny was significantly greater than that of COLE REF individuals, $63.9 \%$ greater in $F_{1}$ and $38.6 \%$ greater in $\mathrm{F}_{2}$, respectively (Fig. $4 \mathrm{~A}$ ), indicating that hybridization with COTI increased the aboveground plant biomass of COLE $F_{1}$ and $F_{2}$ progeny (Table 3 ). On the other hand, the mean DW of COTI $F_{1}$ was only increased slightly $(5.8 \%)$ over the mean DW of COTI REF, and furthermore, the mean DW of COTI $\mathrm{F}_{2}$ was $10.3 \%$ lower than the mean DW of COTI REF.

When data from all COLE $F_{1}$ and COTI $F_{1}$ progeny were combined, the mean $\mathrm{DW}$ of $\mathrm{F}_{1}$ progeny was $0.151 \mathrm{~kg}, 25.9 \%$ greater than the midparent value $(0.120 \mathrm{~kg})$ for DW, suggesting the presence of heterosis in the $F_{1}$ generation (Table 3). COLE $\mathrm{F}_{1}$ and COTI $\mathrm{F}_{1}$ showed $13.8 \%$ and $38.1 \%$ greater $\mathrm{DW}$ than the midparent value, respectively. The heterotic effect was strong in COTI $\mathrm{F}_{1}$.

The mean DW of all COLE $\mathrm{F}_{2}$ and COTI $\mathrm{F}_{2}$ progeny was $0.128 \mathrm{~kg}$, close to the midparent value $(0.120 \mathrm{~kg})$ but $15.3 \%$ lower than that mean DW of all COLE $F_{1}$ and COTI $F_{1}(0.151$ $\mathrm{kg}$ ), suggesting a reduction or breakdown of the heterosis in $\mathrm{F}_{2}$ generation (Table 3). The percentage of DW reduction from $\mathrm{COLE} \mathrm{F}_{1}$ to COLE $\mathrm{F}_{2}(15.4 \%)$ was similar to that from COTI $F_{1}$ to COTI $F_{2}(15.2 \%)$ (Fig. $\left.4 \mathrm{~A}\right)$.

\section{Reproduction of $F_{1}$ and $F_{2}$ hybrids under field conditions}

Time To FLOWER. Significant differences were observed among populations and between years for TTF (Table 1). The mean TTF for each of the six populations in 2010 was significantly greater than that in $2009: 6.0 \%$ to $8.3 \%$ increase for COLE REF and COTI REF, $0.3 \%$ to $4.7 \%$ increase for COLE $\mathrm{F}_{1}$ and COTI $\mathrm{F}_{1}$, and $6.3 \%$ to $7.8 \%$ increase for COLE $\mathrm{F}_{2}$ and COTI $\mathrm{F}_{2}$ (Fig. $3 \mathrm{C}$ and D).

In 2009 and 2010, plants of COLE REF (107.3 and $113.7 \mathrm{~d}$, respectively) took significantly shorter TTF $(7.0 \mathrm{~d}$ fewer in 2009 and $10.0 \mathrm{~d}$ fewer in 2010) than COTI REF (114.2 and $123.7 \mathrm{~d}$, respectively) (Table 3; Fig. 3C and D). However, COLE $F_{1}$ and COTI $F_{1}$ had similar TTF values in 2009 and 2010 as well as COLE $F_{2}$ and COTI $F_{2}$ in 2010.

On average, COLE $\mathrm{F}_{1}$ progeny came to flower $9.8 \mathrm{~d}$ later than COLE REF in 2009 and $3.7 \mathrm{~d}$ later than COLE REF in 2010. COLE $F_{2}$ progeny also came to flower later than COLE REF, $3.8 \mathrm{~d}$ in 2009 and $6.2 \mathrm{~d}$ in 2010 . These data indicate that hybridization with COTI delayed COLE progeny's flowering by 3 to $10 \mathrm{~d}$ (Fig. $3 \mathrm{C}$ and $\mathrm{D}$ ), and COLE $\mathrm{F}_{1}$ and $\mathrm{F}_{2}$ progeny expressed a heterotic effect (Table 3 ). Individuals of COTI REF, COTI $F_{1}$, and COTI $F_{2}$ exhibited similar TTF values in 2009 (114.2 to 115.1) and again in 2010 (120.5 to 123.7), indicating that hybridization with COLE did not make COTI progeny flowering earlier (Table 3 ). 
Table 3. Differences between Coreopsis leavenworthii (COLE) and C. tinctoria (COTI) in six plant characteristics and effects of interspecific hybridization between COLE and COTI on their $\mathrm{F}_{1}$ and $\mathrm{F}_{2}$ progeny in six plant characteristics.

\begin{tabular}{|c|c|c|c|c|}
\hline \multirow[b]{2}{*}{ Characteristics } & \multirow{2}{*}{$\begin{array}{c}\text { Differences between } \\
\text { species }^{\mathrm{z}}\end{array}$} & \multicolumn{2}{|c|}{ Observed effects of interspecific hybridization ${ }^{y}$} & \multirow{2}{*}{$\begin{array}{c}\text { Maternal } \\
\text { effects }\end{array}$} \\
\hline & & In $\mathrm{F}_{1}$ hybrids & In $\mathrm{F}_{2}$ hybrids & \\
\hline Plant height & $\begin{array}{l}\text { COLE: } 25.8-25.9 \mathrm{~cm} \\
\text { shorter }\end{array}$ & $\begin{array}{l}\text { COLE }_{1} \text { : Significant increase from } \mathrm{P} \\
\text { COTI } \mathrm{F}_{1} \text { : Some decrease from } \mathrm{P} \\
\text { All } \mathrm{F}_{1} \text { : Similar to mid-P (no effects) }\end{array}$ & $\begin{array}{l}\text { COLE } \mathrm{F}_{2} \text { : Significant increase from } \mathrm{P} \text {, } \\
\text { similar to } \mathrm{F}_{1} \\
\text { COTI } \mathrm{F}_{2:} \text { : Some decrease from } \mathrm{P} \text {, } \\
\quad \text { similar to } \mathrm{F}_{1} \\
\text { All } \mathrm{F}_{2} \text { : Similar to mid-P and } \mathrm{F}_{1} \\
\quad \text { (no effects) }\end{array}$ & Yes \\
\hline $\begin{array}{l}\text { Pollen } \\
\quad \text { stainability }\end{array}$ & $\begin{array}{l}\text { COLE and } \\
\text { COTI: Similar }\end{array}$ & $\begin{array}{l}\text { COLE } F_{1} \text { : Significant decrease from } \mathrm{P} \\
\text { COTI } \mathrm{F}_{1} \text { : Significant decrease from } \mathrm{P} \\
\text { All } \mathrm{F}_{1} \text { : Significant decrease }\end{array}$ & $\begin{array}{l}\text { COLE } F_{2}: \text { Significant decrease from } \mathrm{P} \text {, } \\
\text { similar to } \mathrm{F}_{1} \\
\text { COTI } \mathrm{F}_{2}: \text { Significant decrease from } \mathrm{P} \text {, } \\
\text { similar to } \mathrm{F}_{1} \\
\text { All } \mathrm{F}_{2}: \text { Significant decrease }\end{array}$ & No \\
\hline $\begin{array}{l}\text { Seed } \\
\quad \text { production }\end{array}$ & COLE: more seed/head & $\begin{array}{l}\text { COLE } F_{1} \text { : Significant reduction from } \mathrm{P} \\
\text { COTI } \mathrm{F}_{1} \text { : Significant reduction from } \mathrm{P} \\
\text { All } \mathrm{F}_{1} \text { : Significant reduction from } \mathrm{P}\end{array}$ & $\begin{array}{l}\mathrm{COLE}_{2} \text { : Significant reduction from } \mathrm{P} \text {, } \\
\text { similar to } \mathrm{F}_{1} \\
\mathrm{COTI}_{2} \text { : Slight reduction from } \mathrm{P}, \\
\text { similar to } \mathrm{F}_{1} \text {. } \\
\text { All } \mathrm{F}_{2}: \text { Significant reduction from } \mathrm{P}, \\
\text { slight recovery from } \mathrm{F}_{1}\end{array}$ & No \\
\hline $\begin{array}{l}\text { Seedling } \\
\text { emergence }\end{array}$ & $\begin{array}{l}\text { COLE: } \sim 13 \% \text { lower } \\
\text { seedling emergence }\end{array}$ & $\begin{array}{l}\text { COLE }_{1} \text { : Similar to P } \\
\text { COTI } F_{1} \text { : Similar to P } \\
\text { All } \mathrm{F}_{1} \text { : Similar to mid-P (no } \\
\text { obvious effects) }\end{array}$ & $\begin{array}{l}\text { COLE } F_{2}: \text { Similar to } P \text { and } F_{1} \\
\text { COTI } F_{2}: \text { Similar to } P \text { and } F_{1} \\
{\text { All } F_{2}: \text { Similar to mid-P (no obvious effects) }} \text { Sim }\end{array}$ & No \\
\hline
\end{tabular}

${ }^{\mathrm{z}}$ Differences between COLE and COTI for each plant characteristic were identified by comparing two parental populations COLE REF and COTI REF in the 2009 and 2010 field studies.

${ }^{y}$ Effects of interspecific hybridization between COLE and COTI on their $F_{1}$ and $F_{2}$ progeny were recognized by comparing 1 ) COLE $F_{1}$ to COLE REF; 2) COTI $F_{1}$ to COTI REF; 3$)$ all $F_{1}\left(C O L E F_{1}\right.$ and COTI $\left.F_{1}\right)$ to the midparent value of COLE REF and COTI REF; 4) COLE $F_{2}$ to COLE REF and $\mathrm{COLE}_{1}$; 5) COTI $\mathrm{F}_{2}$ to COTI REF and COTI $\mathrm{F}_{1}$; and 6$)$ all $\mathrm{F}_{2}\left(\mathrm{COLE} \mathrm{F}_{2}\right.$ and $\left.\mathrm{COTI}_{2}\right)$ to the midparent value and all $\mathrm{F}_{1}\left(\mathrm{COLE} \mathrm{F}_{1}\right.$ and COTI $F_{1}$ ) in the 2009 and 2010 field studies; $F_{1}=$ the COLE $F_{1}$ population (in comparisons with the COLE $F_{2}$ population) or the COTI $F_{1}$ population (in comparisons with the COTI $F_{2}$ population); mid-P = the midparent value of COLE and COTI calculated from the COLE REF and COTI REF populations; $\mathrm{P}=$ the COLE REF population (in comparisons with the COLE $\mathrm{F}_{1}$ ) or the COTI REF population (in comparisons with the COTI $\left.\mathrm{F}_{1}\right)$.

There were very significant interactions between year and the effect of interspecific hybridization on TTF. In 2010, the mean TTF for COLE $F_{1}$, COLE $F_{2}$, COTI $F_{1}$, and COTI $F_{2}$ was 117.4, 119.9, 120.5, and $121.9 \mathrm{~d}$, respectively (Fig. 3D), all similar to the midparent value (117.6 d) (Table 3) and not showing any heterotic, hybrid breakdown or maternal effects. However, when plants were grown in 2009 , two $F_{1}$ populations $\left(\right.$ COLE $F_{1}$ and COTI $\left.F_{1}\right)$ had a mean TTF of $116.1 \mathrm{~d}$ greater than their midparent value $(110.8 \mathrm{~d})$. Thus, the $F_{1}$ seemed to show a heterotic effect in 2009 (Table 3).

Pollen stainability. The mean PS of COLE REF (20.1\%) and COTI REF (16.7\%) was not significantly different (Fig. 4B). The mean PS for COLE $F_{1}$ and COTI $F_{1}$ was $3.8 \%$ and $6.9 \%$, respectively, indicating that the interspecific hybrids had PS significantly lower than COLE REF's $(81.1 \%$ lower) or COTI REF's value $(58.9 \%$ lower) and the midparent value $(18.4 \%$ pollen stainability) (Table 2). The mean PS for COLE $\mathrm{F}_{2}$ and COTI $F_{2}$ was $6.1 \%$ and $7.8 \%$, respectively, which was less than the midparent value, significantly lower than COLE REF's (69.7\% lower) and COTI REF's values (53.3\% lower), but similar to COLE $F_{1}$ 's and COTI $F_{1}$ 's values.

SEED PROdUCTION BY $F_{1}$ AND $F_{2}$ HYBRIDS IN OPEN-POLLINATED FIELDS. There were significant differences between years and among the populations for SP per five seed heads in openpollinated fields (Table 1). The mean SP of the six populations in 2010 was significantly greater than that in $2009: 31.9 \%$ to $44.3 \%$ higher for COLE REF and COTI REF populations, $51.0 \%$ to $78.8 \%$ higher for COLE and COTI $F_{1}$ populations, and $41.8 \%$ to $77.1 \%$ higher for COLE and COTI $F_{2}$ populations (Fig. 3E and F).

In 2009, COLE REF produced significantly more seed (476.0) than COTI REF (416.2) (Fig. 3E). In 2010, COLE 


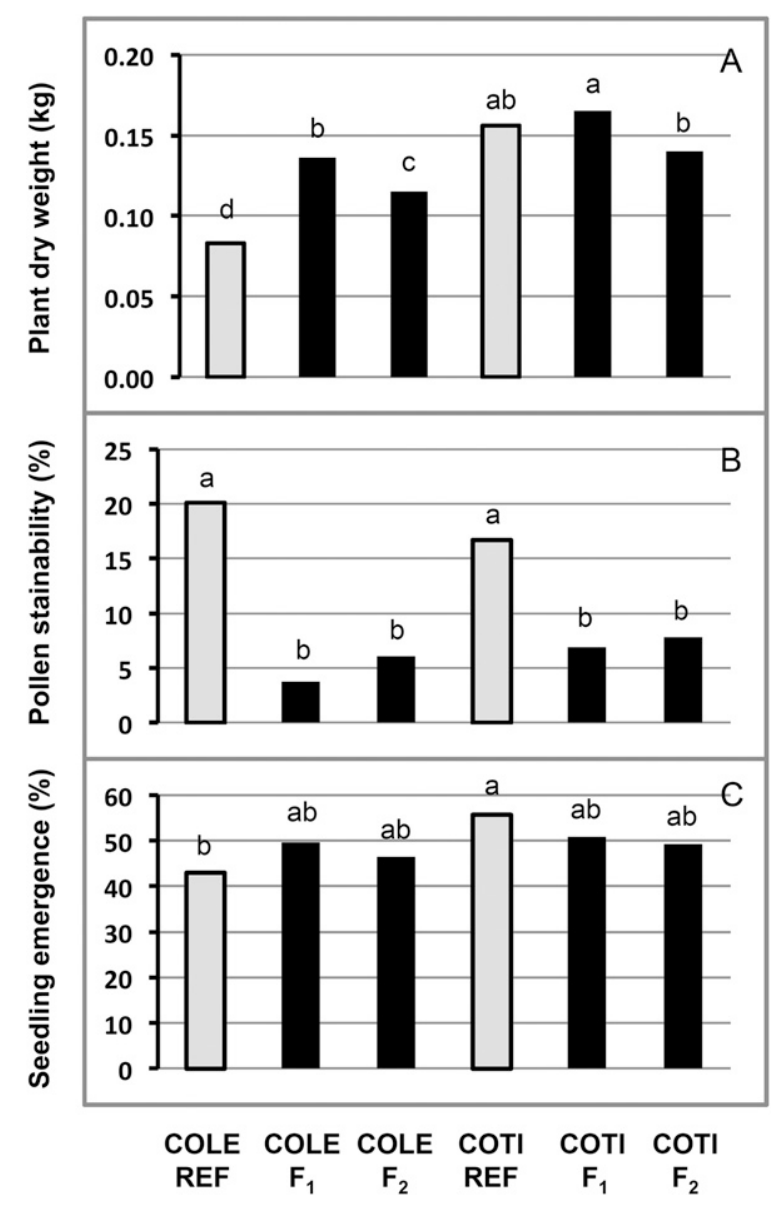

Fig. 4. Mean plant dry weight (A), mean pollen stainability (B), and mean seedling emergence $(\mathbf{C})$ of six populations. $\mathrm{COLE}=$ Coreopsis leavenworthii, and $\mathrm{COTI}=C$. tinctoria. COLE REF $=$ progeny of COLE intraspecific outcrosses, COLE $F_{1}=$ interspecific $F_{1}$ progeny of COLE and COTI, COLE $\mathrm{F}_{2}=$ interspecific $\mathrm{F}_{2}$ progeny of COLE and COTI, COTI REF = progeny of COTI intraspecific outcrosses, COTI $F_{1}=$ interspecific $F_{1}$ progeny of COTI and COLE, and COTI $\mathrm{F}_{2}=$ interspecific $\mathrm{F}_{2}$ progeny of COTI and COLE. Means within year followed by the same letter are not significantly different by Tukey's Studentized range test at $P \leq 0.05$.

REF again produced more seed (627.9) than COTI REF (600.4), although the difference (27.5 seed) was not statistically significant (Fig. 3F).

COLE $\mathrm{F}_{1}$ produced significantly less seed than COLE REF in 2009 (294.0 vs. 476.0) and in 2010 (525.8 vs. 627.9) (Fig. 3E and $\mathrm{F}$ ). Like COLE $\mathrm{F}_{1}, \mathrm{COLE}_{2}$ also produced significantly less seed than COLE REF in both years (309.7 vs. 476.0 in 2009 and 548.6 vs. 627.9 in 2010). These data indicated that hybridizing with COTI caused a significant reduction $(12.6 \%$ to $38.2 \%$ ) in SP by COLE $F_{1}$ and $F_{2}$ progeny.

A significant $\mathrm{SP}$ reduction was also observed in COTI $\mathrm{F}_{1}$. COTI $_{1}$ individuals produced an average of 336.9 seed in 2009 and 508.7 seed in 2010, 19.1\% and 15.3\% less than COTI REF's SP in 2009 (416.2 seed) and in 2010 (600.4 seed).

Pooled interspecific $\mathrm{F}_{1}$ hybrids $\left(\mathrm{COLE} \mathrm{F}_{1}\right.$ and $\left.\mathrm{COTI}_{1}\right)$ had 315.4 SP in 2009 and 517.2 SP in 2010 (Table 2), which represented $29.3 \%$ and $15.8 \%$ reduction from the midparent value in 2009 (446.1 seed) and 2010 (614.1 seed), respectively. Pooled interspecific $\mathrm{F}_{2}$ hybrids had 344.2 SP in 2009 and 542.9 SP in 2010 (Table 2), which was $22.8 \%$ and $11.6 \%$ reduction from the midparent value in 2009 and 2010, respectively. On average, $\mathrm{F}_{2}$ hybrids produced $9.1 \%$ more seed in 2009 and $5.0 \%$ more seed in 2010 than $F_{1}$ hybrids, which might suggest a partial recovery of female fertility in $F_{2}$. Overall, these data showed that reduced $\mathrm{SP}$ was common in interspecific $\mathrm{F}_{1}$ and $\mathrm{F}_{2}$ progeny of COLE and COTI.

SEEDLING EMERGENCE OF OPEN-POLLINATEd F 1 AND F 2 PROGENY. There were significant differences among populations in seedling emergence for the seed collected from open pollinations in the field in 2009 (Table 1). The mean seedling emergence for COLE REF (42.9\%) was significantly lower than COTI REF's value $\left(55.7 \%\right.$ ) (Fig. 4C). The seedling emergence for COLE $\mathrm{F}_{1}$ was $49.7 \%$ and for COTI $F_{1}$ was $50.9 \%$, similar to COLE REF's or COTI REF's value and the midparent value (49.3\%) (Table 2). The mean seedling emergence for COLE $\mathrm{F}_{2}$ seed was $46.4 \%$ and for COTI $\mathrm{F}_{2}$ seed was $49.3 \%$, both similar to the midparent value and COLE $F_{1}$ 's and COTI $F_{1}$ 's values. These results showed that $F_{1}$ and $F_{2}$ populations were not significantly different from COLE REF or COTI REF and that interspecific hybridization between COLE and COTI had no obvious effects on seedling emergence (Table 3).

\section{Discussion}

Cross-COMPATIBILITY AND DifFERENCES IN SEED PRODUCTION BETWEEN COLE AND COTI. COLE produced $23.3 \%$ more seed per seed head when hand-pollinated with COTI pollen than when hand-pollinated with COLE pollen. A similar increase in seed production $(16.2 \%)$ was observed when five COLE plants were hand-pollinated with pollen from five COTI plants (Smith and Deng, 2012). There was an even greater increase in seed production when COTI was hand-pollinated with COLE pollen in this study [67.8\% (Fig. 2A)] and in a previous study (49.7\%) (Smith and Deng, 2012). These results suggest that COLE and COTI are sexually cross-compatible and their pollen seemed to be mutually "stimulating" for seed production. The "stimulating" effect of COLE pollen on COTI flowers was greater than the stimulating effect of COTI pollen on COLE flowers. Previous studies showed that there was a multiallelic, monogenic system of self-incompatibility in COTI (Sharma, 1971). COLE is an obligate outcrosser (Czarnecki et al., 2007), and a similar self-incompatibility system may exist in COLE (Smith and Deng, 2012). It is likely that part of the "stimulating" effect of COLE pollen on COTI flowers or COTI pollen on COLE flowers was the result of the absence of the inhibitory effects from self-incompatibility alleles in these interspecific crosses.

With high levels of cross-compatibility between COLE and COTI in hand pollinations, it would be expected that the two species would cross-pollinate and produce interspecific hybrids frequently in the field. However, only low rates of natural crosspollination were observed between the two species in the fields in central Florida (Smith and Deng, 2012). The highest rate of interspecific cross-pollination or gene flow observed in a 2-year field study was $4.2 \%$ (Smith and Deng, 2012). The discrepancy between expected and observed cross-pollination rates may suggest the existence of isolation mechanisms in COLE and/or COTI that limit natural hybridization between the two species. Floral character-based species isolation (floral isolation) is common in many plants (Grant, 1993). The most obvious difference between COLE and COTI in flowers is the presence of a large brown-red spot at the base of COTI's ray flowers (Smith and Deng, 2012). COLE ray flowers are bright yellow without any brown-red spots. Previous studies have shown that 
flower colors could play important roles in attracting or repelling certain pollinators to visit and pollinate flowers. Jones et al. (1986) showed that some bees preferred the dark knee color over light color in lotus (Lotus corniculatus L.) for foraging and pollination. Reportedly, white corolla color could limit hybridization of Phlox pilosa L. with pink-flowered Phlox glaberrima L. (Levin and Schaal, 1970). It will be interesting to test if the difference between COLE and COTI in flower color plays any role in limiting natural hybridization between these species.

COLE intraspecific crosses produced $236.9 \%$ more seed per seed head than COTI intraspecifc crosses when their flowers were hand-pollinated (Fig. 2A). A similar phenomenon was observed in a previous study, where COLE intraspecific crosses produced $150.8 \%$ more seed than COTI intraspecific crosses (Smith and Deng, 2012). When the two percentages were averaged, COLE flower heads produced $\approx 1.9$ times more seed per head than COTI flower heads. COLE flower heads also produced more seed than COTI flower heads when they were cross-pollinated. However, the difference between two species in seed production became smaller when cross-pollinated. In this study, COLE $\times$ COTI crosses produced $147.6 \%$ more seed than COTI $\times$ COLE crosses (Fig. 2A). In a previous study, COLE $\times$ COTI crosses produced $96.7 \%$ more seed than COTI $\times$ COLE crosses (Smith and Deng, 2012). When data from the two studies were averaged, COLE flower heads produced $\approx 1.2$ times more seed than COTI flower heads when the two species were cross-pollinated.

INTERSPECIFIC HYBRIDIZATION AFFECTED COLE AND COTI PROGENY DIFFERENTLY. COLE and COTI differed in a number of quantitative traits, including $\mathrm{H}, \mathrm{DW}$, and TTF. Overall, plants of COLE were shorter and lighter and flowered earlier than plants of COTI when grown in the field in central Florida (Table 3). When COLE and COTI were hybridized, different responses were observed in their progeny relative to parental plants. Hybridization with COTI significantly increased COLE $F_{1}$ and $\mathrm{F}_{2}$ progeny's $\mathrm{H}, \mathrm{DW}$, and TTF when compared with COLE REF (Table 3). On the other hand, hybridization with COLE did not cause significant changes in COTI $F_{1}$ and $F_{2}$ progeny's $H$, DW, and TTF relative to COTI REF (Table 3). This suggests that COTI played a more dominant role in controlling $\mathrm{H}, \mathrm{DW}$, and TTF in its interspecific hybrids with COLE.

Compared with COLE REF and COTI REF, both $\mathrm{F}_{1}$ (COLE $\mathrm{F}_{1}$ and $\mathrm{COTI} \mathrm{F}_{1}$ ) and $\mathrm{F}_{2}$ populations $\left(\mathrm{COLE} \mathrm{F}_{2}\right.$ and COTI $\mathrm{F}_{2}$ ) showed significant reduction in PS and SP, indicating that interspecific hybridization between COLE and COTI resulted in severe deleterious effects and much reduced fitness in their hybrid progeny.

Previous studies reported $13 \%$ to $31 \%$ PS for a small number of $\mathrm{F}_{1}$ hybrids of COLE and COTI grown in the greenhouse (Smith, 1976). The PS observed in the present study was much lower. There were a number of differences between this and the previous study, including growing conditions (open field vs. closed greenhouse; subtropical climate vs. temperate climate), and vital dyes used (lactophenol cotton blue vs. aniline blue). High temperatures and low relative humidity at anthesis are known to have a detrimental effect on Asteraceae pollen vitality/stainability (Hoekstra and Bruinsma, 1975). Pollen grains collected from the greenhouse had higher stainability (personal observation). In this study, only large, plump pollen grains stained to a uniform, deep blue were considered stainable. Some of these factors might have contributed to the remarkable differences between the present and the previous studies in $\mathrm{F}_{1}$ PS. Nevertheless, both studies showed a dramatic reduction in the PS or viability of interspecific hybrids of COLE and COTI.

INTERSPECIFIC HYBRIDIZATION AFFECTED PROGENY GROWTH, DEVELOPMENT, AND REPRODUCTION DIFFERENTLY. Overall, interspecific hybridization between COLE and COTI did not seem to affect their $F_{1}$ and $F_{2}$ progeny's $H$ and $E$ but affected progeny's DW, TTF, PS, and SP and affected these fitness components in different ways. Heterosis seemed to be evident in $F_{1}$ progeny's TTF in 2009 . Heterosis was also evident in $F_{1}$ progeny's DW but followed with slight hybrid breakdown in $\mathrm{F}_{2}$ progeny. $\mathrm{PS}$ and $\mathrm{E}$ both showed significant breakdown in $\mathrm{F}_{1}$ and $\mathrm{F}_{2}$ progeny. Similar effects of interspecific hybridization have been reported in other species. For example, interspecific $\mathrm{F}_{1}$ hybrids of cultivated rice (Oryza sativa L.) and a wild rice species (Oryza rufipogon Griffiths) exhibited heterosis in the days to flowering and the number of tillers and panicles but suffered breakdown in seedling survival rate, pollen viability, and seed set (Song et al., 2004). Interspecific hybridization between weedy Brassica napus L. and oilseed rape (Brassica rapa $\mathrm{L}$.) resulted in heterosis in one characteristic (the number of pods per offspring plant) but breakdown in another characteristic (the number of seed per pot) in $\mathrm{F}_{1}$ generation, whereas there were no effects on a third characteristic (plant survival from Day 17 to harvest) (Hauser et al., 1998).

Hybrid vigor and hybrid breakdown have been observed in different characteristics after hybridizing different ecotypes of certain species (Hufford and Mazer, 2003; Johansen-Morris and Latta, 2006). It was believed that separate genetic mechanisms underline the two different fitness consequences or outcomes (Hufford and Mazer, 2003; Johansen-Morris and Latta, 2006). Hybrid vigor typically arises through dominance and is a function of heterozygosity in the hybrids, although overdominance or epistasis may also contribute. Hybrid breakdown occurs primarily through epistatic interactions and is a function of recombination, which causes the breakup of coadapted gene complexes or the creation of maladapted combinations (Johansen-Morris and Latta, 2006). It seems reasonable to suspect that similar genetic mechanisms worked in the $\mathrm{F}_{1}$ and/or $\mathrm{F}_{2}$ hybrids of COLE and COTI. However, we suspect that another genetic mechanism might have played an even greater role in the PS and SP of COLE-COTI hybrids. COLE and COTI share the same chromosome number $(2 n=$ $2 x=24)$ but carry at least two translocations between their chromosomes (Smith, 1976). Such kind of chromosomal abnormity can cause partial male and female sterility in plants (Griffiths et al., 2000). We suspect that chromosome mispairing resulting from structural abnormities might be the primary cause of low PS and SP in the $F_{1}$ and $F_{2}$ progeny of COLE and COTI. Maternal effects were detected in the expression of $\mathrm{H}$ and DW in the $F_{1}$ and $F_{2}$ progeny of COLE and COTI crosses. This kind of effect was also obvious in previous studies. For example, $\mathrm{F}_{1}$ hybrids of Iris hexagona Walter $\times$ Iris fulva Ker Gawl. showed a much greater mean leaf area at 38 weeks after seed germination than $F_{1}$ hybrids of the reciprocal cross of the two species (Burke et al., 1998), and $\mathrm{F}_{1}$ hybrids of B. napus $\times$ $B$. rapa exhibited a greater proportion of fully developed seed than $\mathrm{F}_{1}$ hybrids of the reciprocal cross $B$. rapa $\times B$. napus (Hauser et al., 1998). Nevertheless, few discussions have been directed toward the roles of maternal effects in influencing fitness or fitness components of interspecific hybrids. Ours and 
these previous studies suggest that maternal effects can be an important factor affecting hybrid progeny's growth and development.

EFFects of CUltural PRACTICES AND ENVIRONMENTAL CONDITIONS ON PROGENY. Highly significant differences were detected between 2009 and 2010 in progeny's H, TTF, and SP, except DW (Table 1). This was expected because irrigation and fertilization practices used in the two growing seasons were different. In 2009, Coreopsis plants were irrigated through drip tapes and supplied with a high rate of fertilization, whereas in 2010, Coreopsis plants were irrigated through a seepage system without supplemental fertilizers. The growing conditions in the 2009 growing season were similar to cultural practices commonly used in COLE seed production and the growing conditions in 2010 were more similar to the typical habits of COLE [roadside ditches, wet pine flatwoods, and other moist disturbed sites (Kabat et al., 2007)]. Nevertheless, the six Coreopsis populations showed similar overall differences in both years in the traits or fitness components examined. Interestingly, Coreopsis plants were taller but produced fewer seed per seed head in 2009 when fertilizers were provided than in 2010 when no supplemental fertilizers were provided (Fig. $3 \mathrm{~A}, \mathrm{~B}, \mathrm{E}$, and F). More studies are needed to determine the optimal fertility level for Coreopsis seed production (Norcini et al., 2006).

IMPLICATIONS FOR PRODUCTION, PLANTING, PRESERVATION, AND IMPROVEMENT OF Coreopsis. The present study examined the growth, development, and reproduction of as many as 750 $\mathrm{F}_{1}$ hybrids and $750 \mathrm{~F}_{2}$ hybrids of COLE and COTI crosses and showed that their hybrids exhibited much reduced pollen stainability and produced significant fewer seed per seed head. Thus, hybridization between COLE and COTI resulted in deleterious effects to the genotypes of $C$. leavenworthii and C. tinctoria used in this study, which extended to the $\mathrm{F}_{2}$ generation and, potentially, to even later generations. If similar adverse effects exist after interspecific hybridization between other genotypes of these two species, it will be very important to prevent interspecific hybridization or cross-pollination between these two species in commercial seed production and native planting for highway revegetation and ecological restoration. A previous study demonstrated that physical separation was an effective tool for minimizing cross-pollination between these two species (Smith and Deng, 2012). We would recommend implementation of physical separation (or other physical barriers) in seed production and planting of $C$. leavenworthii or C. tinctoria, if necessary.

Coreopsis is widely distributed in the United States (Smith, 1976). A number of states have included Coreopsis species on their list of wildflower species for highway beautification (Texas Department of Transportation, 2011). It is known that interspecific hybridization can occur among a number of Coreopsis species (Archibald et al., 2005; Smith, 1976). Greenhouse studies indicated that some of the $F_{1}$ hybrids between cross-compatible Coreopsis species were partially sterile (Smith, 1976). Field studies are needed to assess the full effects of such interspecific hybridization on progeny growth, development, and reproduction. Before such assessments are done, caution may be necessary to avoid or minimize unintended interspecific hybridization when growing or planting crosscompatible Coreopsis species.

Cultivated Coreopsis has become a mainstay of gardens in the United States (Jourdan and Stieve, 2013). Cultivars have been developed in COTI, $C$. grandiflora Hogg ex Sweet $(2 n=$ $2 x=26), C$. verticillata L. $(2 n=2 x=26$ or $2 n=4 x=52)$, C. lanceolata L. $(2 n=2 x=26), C$. rosea Nutt. $(2 n=2 x=26)$, C. auriculata L. $(2 n=2 x=26)$, and C.tripteris L. $(2 n=2 x=26)$ (Jourdan and Stieve, 2013; Smith, 1976). Although several of these species share the same chromosome numbers, they may have chromosomal structural differences. Interspecific hybridization among these species, if successful, will likely result in reduced male and/or female fertility in progeny. This will be a significant problem for seed-propagated Coreopsis cultivars. In such case, it will be necessary to increase female fertility to a level to make commercial seed production viable. Alternatively, breeding may focus on intraspecific crossing and mutation induction for further improvement of cultivated Coreopsis.

\section{Literature Cited}

Archibald, J.K., M.E. Mort, D.J. Crawford, and J.K. Kelly. 2005. Life history affects the evolution of reproductive isolation among species of Coreopsis (Asteraceae). Evolution 59:2362-2369.

Bryant, B. and B.L. Harper-Lore. 1997. Where wildflowers bloom, so does hope. 20 June 2011. <http://www.fhwa.dot.gov/publications/ publicroads/97novdec/p97nov38.cfm $>$.

Burke, J.M., S.E. Carney, and M.L. Arnold. 1998. Hybrid fitness in the Louisiana irises: Analysis of parental and $\mathrm{F}_{1}$ performance. Evolution $52: 37-43$.

Czarnecki, D.M., II, J.F. Norcini, and Z. Deng. 2007. Phenotypic diversity of Coreopsis leavenworthi. Native Plants J. 8:45-57.

Ellstrand, N.C. 1992. Gene flow by pollen: Implications for plant conservation genetics. Oikos 63:77-86.

Florida Legislature. 2014. The 2014 Florida statutes. 1 Sept. 2014. $<$ http://www.leg.state.fl.us/Statutes/index.cfm?App_mode=Display_ Statute\&URL=0000-0099/0015/0015.html $>$.

Geraldson, C.M., A.J. Overman, and J.P. Jones. 1965. Combination of high analysis fertilizers, plastic mulch and fumigation for tomato production on old agricultural land. Proc. Soil Crop Sci. Soc. Fla. 25:18-24.

Grant, V. 1993. Effects of hybridization and selection on floral isolation. Proc. Natl. Acad. Sci. USA 90:990-993.

Griffiths, A.J.F., J.H. Miller, D.T. Suzuki, R.C. Lewontin, and W.M. Gelbart. 2000. An introduction to genetic analysis. 7th Ed. Freeman, New York, NY.

Hauser, T.P., R.G. Shaw, and H. Østergard. 1998. Fitness of $F_{1}$ hybrids between weedy Brassica rapa and oilseed rape (B. napus). Heredity 81:429-435.

Hoekstra, F.A. and J. Bruinsma. 1975. Viability of Compositae pollen: Germination in vitro and influences of climatic conditions during dehiscence. Zeitschrift für Pflanzenphysiologie 76:36-43.

Hufford, K.M. and S.J. Mazer. 2003. Plant ecotypes: Genetic differentiation in the age of ecological restoration. Trends Ecol. Evol. 18:147-155.

Johansen-Morris, A.D. and R.G. Latta. 2006. Fitness consequences of hybridization between ecotypes of Avena barbata: Hybrid breakdown, hybrid vigor, and transgressive segregation. Evolution 60:1585-1595.

Jones, D.A., S.G. Comptan, T.J. Crawford, W.M. Ellis, and I.M. Taylor. 1986. Variation in the colour of the keel petals in Lotus corniculatus L. 3. Pollination, herbivory and seed production. Heredity 57:101-112.

Jourdan, P. and S. Stieve. 2013. Colorful Coreopsis: A theme for 2013. OFA Bul. 938:10-13.

Kabat, S.M., J.G. Norcini, and B. Dehgan. 2007. Temperature and light affect germination ecology of commercially produced seed of leavenworth's coreopsis (Coreopsis leavenworthii). Native Plants J. 8:235-247.

Laikre, L., M.K. Schwartz, R.S. Waples, and N. Ryman. The GeM Working Group. 2010. Compromising genetic diversity in the wild: 
Unmonitored large-scale release of plants and animals. Trends Ecol. Evol. 25:520-529.

Largiadèr, C.R. 2007. Hybridization and introgression between native and alien species. Biol. Invasions 193:275-292.

Levin, D.A., J. Francisco-Ortega, and R.K. Jansen. 1996. Hybridization and the extinction of rare plant species. Conserv. Biol. 10:10-16.

Levin, D.A. and B.A. Schaal. 1970. Corolla color as an inhibitor of interspecific hybridization in Phlox. Amer. Nat. 104:273-283.

Norcini, J.G., J.H. Aldrich, and F.G. Martin. 2006. Harvest season and fertilizer effects on seed production of Leavenworth's coreopsis. J. Environ. Hort. 24:63-67.

Parker, H.M. 1973. A biosystematic study of section Calliopsis of Coreopsis (Compositae). PhD diss., Univ. Arkansas, Little Rock, AR.

Rogers, D.L. and A.M. Montalvo. 2004. Genetically appropriate choices for plant materials to maintain biological diversity. Univ. California. Rpt. to U.S. Dept. Agr. Forest Serv., Rocky Mountain Region, Lakewood, CO. SAS Institute. 1997. SAS users guide. SAS Inst., Cary, NC.

Sharma, J.N. 1971. The genetics, nature and occurrence of selfincompatibility and cross-incompatibility in four annual species of Coreopsis L. PhD diss., Montana State Univ., Bozeman, MT.
Smith, E.B. 1976. A biosystematic survey of Coreopsis in eastern United States and Canada. SIDA 6:123-215.

Smith, S.M. and Z. Deng. 2012. Pollen-mediated gene flow from Coreopsis tinctoria to Coreopsis leavenworthii: Inheritance of morphological markers and determination of gene flow rates as affected by separation distance. J. Amer. Soc. Hort. Sci. 137:173179.

Song, Z.P., B.R. Lu, B. Wang, and J.K. Chen. 2004. Fitness estimation through performance comparison of $\mathrm{F}_{1}$ hybrids with their parental species Oryza rufipogon and O. sativa. Ann. Bot. (Lond.) 93:311-316. Texas Department of Transportation. 2011. Wildflower facts. 20 June 2011. <http://www.txdot.gov/public_involvement/wildflowers/ facts.htm>.

U.S. Department of Agriculture. 2012. The PLANTS database. 31 Aug. 2012. <http://www.plants.usda.gov/java/nameSearch?keywordquery= coreopsis + leavenworthii\&mode $=$ sciname $>$.

Wunderlin, R.P. 1998. Guide to the vascular plants of Florida. Univ. Press of Florida, Gainesville, FL.

Wunderlin, R.P. and B.F. Hansen. 2004. Atlas of Florida vascular plants. 7 May 2011.<http://www.plantsatlas.usf.eud>. 